\title{
MAKANAN YANG HALAL LAGI BAIK \\ DAN IMPLIKASINYA TERHADAP KESALEHAN SESEORANG \\ Oleh: Waharjani
}

Tafsir Hadis Universitas Ahmad Dahlan

\begin{abstract}
Some ways of organisms to survive was by eating, so human being did. Foods was very influential to health and characters of human. Basically human being had sense of Godliness to make their life noble and respected because of obeying God's rule. Therefore, Islam taught human to consume good food for getting individual and social piety.

This paper tried to solve the problem by identifying as the followings: (1) what was kind of food suggested to be consumed by considering its sources? (2) what did the good food mean according to Al-Qur'an? (3) Did the food have implication to the goodness of human? To solve the problem the writer used qualitative method to searched health experts issued in journals and books as well as other scientific books written by Muslim scholars. While suggestion of theologians, the writer searched in commentary of Al-Qur'an, deals of scholars and books about explanation of hadith. From the search the writer would conclude to answer the above problem.

From the literature review, the writer concluded that the good food was the food which was proper to human who want to get individual and social piety, because food must gave contribution of nutrition need of body and be hygiene and legitimate according to Islam. Therefore, the result of this study would be main material in the activity of social dedication by counseling method to society programed by LPM of Ahmad Dahlan University through KKN or Mosque Counseling Program.
\end{abstract}

Keywords: halalan thayyiban; hygienic; natural 
Waharjani : Makanan yang Halal lagi Baik dan Implikasinya

\section{Abstrak}

Diantara cara makhluk hidup mempertahahankan hidupnya adalah dengan makan, demikian juga manusia. Makanan sangat berpengaruh terhadap kesehatan jasmani dan karakter manusia. Pada fitrahnya manusia itu memiliki rasa bertuhan agar hidupnya mulia dan terhormat karena mengikuti aturan tuhan. Oleh karena itu, Islam mengajarkan manusia untuk mengkonkomsi makanan yang halal lagi baik agar dapat mencapai kesalehan pribadi dan sosial.

Makalah ini berikhtiar untuk memecahkan problematika sebagai berikut: (1) jenis makanan apa saja yang dianjurkan untuk dikonsumsi dilihat dari sumbernya? (2) Apakah yang dimaksud makanan yang halal thayyiban dalam Al-Qur'an itu? (3) Apakah makanan itu berimplikasi terhadap kesalehan seseorang? Untuk memecahkan problema tersebut penulis menggunakan metode kualitatif dengan menelusuri pendapat ahli kesehatan yang terdapat dalam jurnal dan buku-buku dan karya ilmiah cendekiawan muslim yang lain. Sedangkan pendapat ulama' penulis telusuri dalam kitab-kitab tafsir Al-Qur'an, ijma' para ulama dan kitab-kitab karya ulama' mengenai penjelasan hadis. Dari penelusuran itu penulis akan menyimpulkan untuk menjawab problema diatas.

Dari hasil kajian pustaka, penulis menyimpulkan bahwa makanan yang halal lagi baik (halalan thayyiban) itu adalah makanan yang tepat bagi manusia yang menginginkan mencapai kesalehan pribadi dan kesalehan sosial, sebab makanan itu memberi konstribusi bagi terpenuhinya nutrisi pada tubuh jasmani dan bersifat hygenis serta sah menurut Islam. Oleh karena itu hasil kajian ini akan menjadi materi pokok dalam kegiatan pengabdian pada masyarakat dengan metode penyuluhan pada masyarakat yang diprogramkan LPM Universitas Ahmad Dahlan lewat KKN maupun program Bina Masjid.

Key word : halalan thayyiban; hygenis; fitrah.

\section{A. Latar Belakang}

Diantara cara makhluk hidup mempertahahankan hidupnya adalah dengan makan, demikian juga manusia. Makanan sangat berpengaruh terhadap kesehatan jasmani dan karakter manusia. 
Makanan atau tha'am dalam bahasa al-Qur'an adalah segala sesuatu yang dimakan atau dicicipi. Karena itu "minuman" pun termasuk dalam pengertian tha'am. Al-Qur'an surat alBaqarah 249 menggunakan kata syariba (minum) dan yath'am (makan) untuk objek yang berkaitan dengan air minum ${ }^{154}$. Menurut M. Quraih Shihab, kata tha'am dalam berbagai bentuknya terulang dalam al-Qur'an sebanyak 48 kali yang antara lain berbicara tentang berbagai aspek berkaitan dengan makanan. Ini menunjukkan perhatian al-Qur'an begitu beasar, sampaisampai pakar tafsir Ibrahim bin Umar Al-Biqa'i menyatakan, "telah menjadi kebiasaan Allah dalam al-Qur'an bahwa Dia menyebut diriNya sebagai Tuhan Yang Maha Esa, serta membuktikan hal tersebut melalui uraian tentang ciptaanNya, kemudian memerintahkan untuk makan (atau menyebut makanan)"155.

Dalam masalah penilaian, sejak dahulu umat manusia berdeda-beda dalam menilai suatu makanan dan minuman mereka, ada yang boleh dan ada yang tidak boleh, lebih-lebih dalam masalah makanan yang berupa binatang. Adapun masalah makanan dan minuman yang berasal dari tumbuhan-tumbuhan, tidak banyak diperselisihkan. Dan Islam sendiri tidak mengharamkan hal tersebut, kecuali setelah menjadi arak, baik yang terbuat dari anggur, korma, gandum ataupun bahan-bahan lainnya, selama benda-benda tersebut sudah mencapai kadar memabukkan. Begitu juga Islam mengharamkan semua benda

${ }^{154}$ M. Quraish Shihab, Wawasan Al-Qur'an. Bandung: Mizan, 1996, hlm. 137

155 Ibid. 
yang dapat menghilangkan kesadaran dan melemahkan urat serta yang membahayakan tubuh ${ }^{156}$.

\section{B. Problematika}

Berdasarkan uraian diatas, maka penulis pada makalah ini mengajukan problematika untuk dipecahkan adalah sebagai berikut:

1. Jenis makanan apa saja yang dianjurkan untuk dikonsumsi dilihat dari sumbernya?

2. Apakah yang dimaksud makanan yang halal thayyiban dalam Al-Qur'an itu?

3. Apakah makanan itu berimplikasi terhadap kesalehan seseorang?

\section{Tujuan Pembahasan}

Adapun tujuan pembahasan mengenai makanan ini adalah sebagai berikut:

1. Untuk mengetahui jenis-jenis makanan yang boleh dikonsumsi dari segi sumbernya.

2. Untuk mengetahui yang dimaksud makanan yang halalan thayyiban dalam al-Qur'an.

3. Untuk mengetahui apakah makanan yang dikonsumsi itu berimplikasi terhadap kesalehan seseorang.

156 Muhammad Yusuf Qardhawi, Haram danHaram dalam Islam, terj. Mu'ammal Hamidi. Surabaya: Bina Ilmu,. 1990, hlm. 50 


\section{Metode Pembahasan}

Untuk memecahkan problematika mengenai makanan tersebut penulis menggunakan metode kualitatif dengan menelusuri pustaka mengenai pendapat ahli kesehatan yang terdapat dalam jurnal dan buku-buku dan karya ilmiah cendekiawan muslim yang lain. Sedangkan pendapat ulama' penulis telusuri dalam kitab-kitab tafsir Al-Qur'an, ijma' para ulama dan kitab-kitab karya ulama' mengenai penjelasan hadis. Dari penelusuran itu penulis akan menyimpulkan untuk menjawab problema diatas.

\section{E. Kontribusi}

1. Manfaat Akademik

Makalah ini berikhtiar untuk memecahkan problematika sebagai berikut: (1) jenis makanan apa saja yang dianjurkan untuk dikonsumsi dilihat dari sumbernya? (2) Apakah yang dimaksud makanan yang halal thayyiban dalam Al-Qur'an itu? (3) Apakah makanan itu berimplikasi terhadap kesalehan seseorang?

Untuk memecahkan problema tersebut penulis menggunakan metode kualitatif dengan menelusuri pendapat ahli kesehatan yang terdapat dalam jurnal dan ulama' penulis telusuri dalam kitab-kitab tafsir Al-Qur'an, ijma' para ulama dan kitab-kitab karya ulama' mengenai penjelasan hadis. Dari penelusuran itu penulis akan menyimpulkan untuk menjawab problema diatas.

2. Manfaat Praktis

Makalah ini disusun dalam rangka menyemarakkan seminar kali ini dan mengembangkan bahan dan materi 
Waharjani : Makanan yang Halal lagi Baik dan Implikasinya

pengabdian pada masyarakat, diantaranya tentang pandangan Islam tentang makanan.

\section{F. Makanan Yang Halal lagi Baik}

Al-Qur'an menyatakan"Dia Allah menciptakan utuk kamu apa yang ada di bumi seluruhnya"157, juga "Dan Dia (Allah) yang telah mencundukkan untuk kamu segala yang ada dilangit dan di bumi semua bersumber dariNya"158. Bertitik tolak dari kedua ayat tersebut dan bewberapa ayat lain, para ulama" berkesikmpulan nbahwa pada prinsipnya segala sesuatu yang ada di alam raya ini adalah halal untuk digunakan., sehingga makanan yang terdapat didalamnya juga adalah halal. Karena disiapkan Allah untuk manusia (QS. Yunus [10]: 59). Pengecualian atau pengharaman harus bersumber dari Allah-baik melalui Al-Qur'an maupun Rasul-sedang pengecualian itu lahir dan disebabkan oleh kondisi manusia, karena raganya. Atas dasar ini turun perintahNya antara lain surat al-Baqarah: 168. Dilihat dari sumbernya makanan yang yang diuraikan dalam al-Qur'an dapat dibagi dalam tiga kategori:

1. Nabati, tidak ditemukan satu ayatpun yang secara eksplisit melarang nabati tertentu159. Kalaupun ada tumbuhtumbuhan tertentu, yang kemudian terlarang maka tersebut termasuk dalam larangan umum memakan sesuatu yang buruk, atau merusak kesehatan.

157 Qur'an surat Al-Baqarah (2): 29

158 Qur'an surat Al-Jatsiyah (45): 13

159 QS. Abasa $\{80\}$ : 24-32 
2. Hewani, jenis ini al-Qur'an membaginya dalam dua kelompok besar, yaitu yang bersal dari laut dan darat.Hewan laut yang hidup di air asin dan tawar dihalalkan Allah ${ }^{160}$.

3. Olahan, seperti khamr itu haram, yang lain melihat prosesnya. Bila kecampuran yang haram sekalipun sedikit dimenangkan hukumnya yang haram ${ }^{161}$. MUI melalui Dinas POM mesyaratkan, bila makanan olahan itu dikemas dengan plasti, atau kerdus, cantumkan tanggal kadaluwarsa, lebel halal, dan komposi bahan-bahan yang dipakai.

Dari hasil kajian pustaka, penulis menyimpulkan bahwa makanan yang halal lagi baik (halalan thayyiban ${ }^{162}$ ) yang diisyaratkan Allah dalam surat al-Baqarah ayat 168 163itu adalah makanan yang tepat bagi manusia yang menginginkan mencapai kesalehan pribadi dan kesalehan sosial, sebab makanan itu memberi konstribusi. Oleh karena itu hasil kajian ini diharapkan akan menjadi materi pokok dalam kegiatan pengabdian pada masyarakat dengan metode penyuluhan yang sedang dan akan Dahlan lewat KKN maupun program Bina Masjid dan bina umat.

\section{G. Makanan yang Haram}

Berdasarkan firman Allah dalam surat al-Maidah ayat 3, surat al-Baqarah 172-173, dan surat al-An'am: 145 menunjukkan bahwa makanan yang berasal dari binatang yang diharamkan Allah adalah: Bangkai (hewan yang mati tercekik; hewan yang

160 QS. An-Nahl \{16\}: 14 dan Al-Maidah: 96

161 Qaidah fiqhiyah: idzajtama'al halalu wal haram ghulibal haram, apabila ada barang yang halal banyak kemasukan yang haram walau sedikit, hukumnya dimenangkan yang haram.

162 Kata thayib dalam makanan adalah makanan yang sehat, prorsional, dan aman, namun mesti halal(hlm. 148). 


\section{Waharjani : Makanan yang Halal lagi Baik dan Implikasinya}

mati dipukul; hewan yang mati sebab terjatuh; mati sebab ditanduk; diterkam binatang lain; hewan yang disembelih untuk berhala), darah, daging babi, dan hewan yang disembelih tanpa baca basmalah. Selain itu, ada yang diharamkan berdasarkan keterangan Rasul, misalnya hewan berkuku tajam, bertaring, dan yang hidup di dua alam.

\section{H. Hikmah memakan makanan yang halal lagi baik}

Makanan yang halalan thayyiban (Q.S. 2: 168) adalah makanan yang dianjurkan Allah Swt. Dan bahkan itulah yang pantas bagi manusia yang mulia (ahsani taqwim). Dan para ulama telah memberikan informasi, agar tetap memberikan makanan yang halal lagi baik, tidak tercampur (sekalipun dikit)yang haram. Mengenai hal terakhir itu ulama telah menetapkan kaedah (fiqhiyah): "Apabila berkumpul barang yang halal dan yang haram (maka hukumnya) dimenangkan yang haram".

Memang seorang muslim dalam keadaan darurat boleh memakan makanan yang haram secara terbatas (Q.S. Al An'am 145).

Orang yang memakan makanan yang haram doa permohonanya tidak di dengar apalagi dikabulkan Allah. Hal itu berdasarkan informasi Rasulullah saw. Dalam hadist Qudsi yang artinya:

" sesungguhnya Allah itu baik tidak menerima sesuatu kecuali yang baik. Dan sesungguhnya Allah memerintahkan pada orang-orang mu'min (serupa) dengan apa yang telah diperintahkan pada para Rasul, maka Allah telah berfirman : Hai Rasul-rasul makanlah dari segala sesuatu yang baik, dan bekerjalah kamu dengan pekerjaan yang baik. Dan telah berfirman : Hai orang-orang yang beriman! Makanlah dari apa-apa yang baik yang telah Kami rizekikan padamu. Kemudian beliau menceritakan seorang laki-laki yang telah jauh perjalananya, berambut kusut penuh dengan debu. Dia 
mengadakan tangannya ke langit dan berkata: wahai Tuhan, wahai Tuhan, sedang makananya haram, maka bagaimana ia akan diterima do'a permohonannya?"(H.R Muslim dari Abu Hurairah) ${ }^{164}$.

Memang kita boleh saja bertanya, dan mencari jawaban tentang mengapa Allah SWT mengharamkan makanan tertentu. Boleh jadi kita puas atau tidak puas dengan jawaban yang diberikan, tetapi adalah amat bijaksana jik jajwaban yang ditemukan itu walaupun sangat memuaskan tidak di jadikan satu-satunya jawaban.

Imam Al-Ghazali memberikan ilustrasi menyangkut illat (katakan sebab atau hikmah) dari larangan-larangan ilahi. Seorang ayah mempunyai anak yang tinggal bersama di suatu rumah. Sebelum kematian menjemputnya, sang ayah mewasiatkan kepada anaknya : "jika kamu ingin memugar rumah ini silakan, tetapi tumbuhan yang terdapat di serambi rumah jangan ditebang", beberapa memadai. Rumah di pugarnya dan ketika sampai di tumbuhan terlarang, ia berpikir, apakah gerangan sebabnya ayah melarang menebangnya? Pikiranya sampai pada kesimpulan bahwa aroma pohon itu harum. Dan sisi lain, ia mengetahui bahwa telah ditemukan tumbuhan lain yang memiliki aroma lebih harum. Maka ia pun memutuskan menebang tumbuhan itu dan menggantikanya dengan tumbuhan yang lebih sedap. Tetapi apa yang terjadi? Tidak lama kemudian muncul seekor ular, yang hampir saja menerkamnya, dan ketika itu ia sadar bahwa rupanya aroma tumbuhan itu, merupakan pangkal kehadiran ular. Ia hanya mengetahui sebagian dari 'illat

164 Imam Nawawi, Hadits Arba'in An Nwawiayah. Beirut: Dar alKutubil Islamiyah, 1959 
Waharjani : Makanan yang Halal lagi Baik dan Implikasinya

laranagan ayahnya, bukan semuanya, bahkan bukan yang terpenting darinya ${ }^{165}$.

\section{Implikasi makanan yang halal lagi baik terhadap kecerdasan dan kesehatan.}

Dalam hal ilmu pengetahuan yang rational, Al Qur'an memberi petunjuk seperti dalam bidang pendidikan, dalam alQur'an surat Maryam (19) ayat 28, bahwa sifat ibu dan bapak diwariskan kepada anaknya. Hal ini menunjukan adanya pendidikan pranatal dan postnatal. Bahkan pendidikan anak berdasarkan hadists, mulai dari pemilihan jodoh, kemudian waktu mengandung, yang segala sifat orang tua berbekas kepada anaknya.

Demikian juga untuk pendidikan pranatal dan postnatal. Al-Qur'an memberi petunjuk agar anak itu sehat dan cerdas. Maka Allah memerintahkan dalam Al-Qur'an surat Al-Baqarah (2) ayat 168 dan 172, untuk memakan makanan yang halal dan thayyibat (makanan yang baik-baik). Harus makan makanan yang halal, karena makanan yang haram yang dimakan oleh seorang menghalangi do'a orang itu kepada Allah. Di dalam hidup, seseorang bekerja, berusaha, tetapi kesuksesan itu ada pada kekuasaan Allah semata Q.S. Al-Qashash (28) ayat 56 dan Q.S. AlIkhlas (112) ayat 2, bahkan Al-Asy'ats, seorang ilmuwan muslim pada akhir abad IV (390 H) telah mengadakan penelitian terhadap makanan halalan thayyiban yang dilaporkan hasilnya dalam buku Al-Hidza'wal Muhtady, bahwa jenis makanan itu ada yang membesarkan tubuh jasmani dan ada yang menumbuhkan kecerdasan, seperti halnya dalam ilmu gizi karbohidrat

165 M. Quraish Shihab, ...hlm. 142. 
menumbuhkan fisik, sedangkan protein akan menumbuhkan kecerdasan. Orang Barat, seperti di Amerika untuk protein diambil dari daging sapi, daging sapi rentan terhadap kolesterol yang dapat membahayakan jantung, maka orang Jepang dengan mengkonsumsi ikan untuk kecukupan asupan protein ${ }^{166}$. Juga tentang pengaruh makanan itu, seorang ulama kontemporer, Syaikh Taqi Falsafi dalam bukunya Child Between Heredity and Education menguatkan pendapatnya dengan mengutip Alexis Carrel pemenang hadiah Nobel Kedokteran. Carrel mengutip dalam bukunya Man the Unknouwn lebih kurang sebagai berikut: "Pengaruh dari campuran (senyawa) yang dikandung oleh makanan terhadap aktivitas jiwa dan pikiran manusia belum diketahui secara sempurna, karena belum lagi diadakan eksperimen secara memadahi. Namun tidak dapat diragukan bahwa perasaan manusia dipengaruhi oleh kualitas dan kuantitas makanan ${ }^{167 .}$

Oleh karena itu, di samping bekerja keras seseorang harus terus berdoa kepada Allah untuk mendapatkan taufiq daripadaNya, yaitu kecocokan antara usaha dan hasil yang ingin dicapai .diantaranya senantiasa mengkonsumsi makanan yang halal lagi baik, dan menghindari makan makanan yang haram agar do'a dan permohonannya diterima oleh Allah swt.

\section{J. Kesimpulan}

Dari pembahasan diatas, maka penulis memberikan kesimpulan sebagai berikut:

166 Waharjani, Makanan yang halal lagi baik dalam Risalah Jum'at edisi 21 tahun 2009

167 M. Quraish Shihab, Wawasan....hlm. 152 
1. Makanan yang dianjurkan untuk dimakan adalah makanan yang halal lagi baik, yang bersumber dari nabati, hewani, dan olahan.

2. Makanan halalan thayyiban adalah makanan yang sah menurut syar'i, baik dan bergizi.

3. Makanan yang tepat bagi manusia yang menginginkan mencapai kesalehan pribadi dan kesalehan sosial, sebab makanan itu memberi konstribusi bagi terpenuhinya nutrisi pada tubuh jasmani dan bersifat hygenis serta sah menurut Islam.

\section{K. Daftar Pustaka}

Al-sy'ats, Al., Al-Hidza' wal Muhtady. Mesir: Darul Fikr, 1969

Departemen Agama RI., Al-Qur'an Dan Terjemahnya. Jakarta: Proyek Pengadaan Kitab Suci Al-Qur'an, 1984/1985

Shihab, Muhammad Quraish, Membumikan Al-Qur'an. Bandung: Mizan, 2008

------------., Wawasan Al-Qur'an. Bandung: Mizan, 1996

Qardhawi, Yusuf, Halal Dan Haram dalam Islam, terj. Mu'ammal Hamidi.Surabaya: Bina Ilmu, 1990

Nawawi, Imam, Hadits Arba'in An Nawawiyah. Beirut: Dar AlKutubil Islamiyah,1959

Waharjani, Risalah Jum'at edisi 21 dan 22 tahun 2009 